\title{
Studi Kasus: Asuhan Keperawatan Jiwa Pada Ny. A Dengan Masalah Halusinasi Penglihatan
}

\author{
Winda Veratami Purba
}

Windap754@gmail.com

\author{
BAB I \\ PENDAHULUAN
}

\subsection{Latar Belakang}

Skizofrenia merupakan salah satu bentuk gangguan jiwa kronik, yang menyebabkan penyakit otak persisten serius yang mengakibatkan perilaku psikotik, pemikiran konkret, dan kesulitan dalam memperoleh informasi. (Pardede. \& Hasibuan, 2020). Seorang yang mengalami skizofrenia terjadi kesulitan berfikir dengan benar, memahami dan menerima realita, gangguan emosi/perasaan, tidak mampu membuat keputusan, serta gangguan dalam melakukan aktivitas atau perubahan perilaku. Pasien skizofrenia 70\% mengalami halusinasi (Stuart, 2013 ).

Menurut World Health Organization (WHO, 2019) Skizofrenia merupakan suatu gangguan jiwa berat yang bersifat berat dan kronis yang menyerang 20 juta orang di seluruh dunia. Skizofrenia merupakan penyakit kronis, parah, dan melumpuhkan, gangguan otak yang di tandai dengan pikiran kacau, waham, delusi, halusinasi, dan perilaku aneh atau katatonik (Pardede \& Laia, 2020). Negara berkembang seperti Indonesia penderita gangguan jiwa dari data yang diambil (Riskesdas, 2018) penderita skizofrenia mengalami peningkatan sebesar 5,3\% terutama untuk skizofrenia berat seperti gangguan perilaku hingga dengan pasung. Kasus tertinggi terdapat di Bali (11\%), Di wilayah Jawa Timur data yang tercatat 2018 penderita skizofrenia sebesar 7,5\% (Riskesdas, 2018). 
Halusinasi merupakan keadaan seseorang mengalami perubahan dalam pola dan jumlah stimulasi yang diprakarsai secara internal atau eksternal disekitar dengan pengurangan berlebihan, distorsi, atau kelainan berespon terhadap setiap stimulasi (Pardede, Silitonga \& Laia, 2020). Menurut Stuart (2016) pasien halusinasi menjadi menarik diri tidak mau menceritakan hal yang mereka alami karena mereka takut lebih mendapatkan pandangan negatif dari orang lain terkait pikiran mereka yang tidak wajar.

Survei awal dilakukan di Yayasan Pemenang Jiwa Sumatra dengan jumlah pasien 70 orang tetapi yang menjadi subjek di dalam pembuatan askep ini berjumlah 1 orang dengan pasien masalah halusinasi penglihatan atas nama inisial Ny. A, penyebabnya Ny. A sebagai subjek di karenakan pasien belum bisa mengatasi halusinasinya selain minum obat. Maka tujuan asuhan keperawatan yang akan di lakukan ialah untuk mengajarkan standar pelaksanaan masalah halusinasi penglihatan pada saat Ny. A mengalami halusinasinya.

\subsection{Rumusan Masalah}

Berdasarkan masalah yang telah dipaparkan pada latar belakang maka rumusan masalah dalam askep ini yaitu : Asuhan Keperawatan Jiwa Pada Ny.

A Dengan : Halusinasi Penglihata Di Yayasan Pemenang Jiwa Sumatera.

\subsection{Tujuan.}

\subsubsection{Tujuan Umum}

Mahasiswa mampu menerapkan asuhan keperawan jiwa pada $\mathrm{Ny}$. A dengan Halusinasi Penglihatan di Yayasan Pemenang Jiwa Sumatera Sumatera. Tujuan Khusus

\subsubsection{Tujuan Khusus}

1. Mahasiswa mampu melakukan pengkajian pada Ny. A dengan gangguan persepsi sensori : halusinasi penglihatan. 
2. Mahasiswa mampu menegakkan diagnosa keperawatan yang ada pada Ny. A dengan gangguan persepsi sensori : halusinasi penglihatan.

3. Mahasiswa mampu menetapkan perencanaan keperawatan pada Ny. A dengan gangguan persepsi sensori : halusinasi penglihatan.

4. Mahasiswa mampu melakukan implementasi keperawatan pada Ny. A dengan gangguan persepsi sensori : halusinasi penglihatan.

5. Mahasiswa mampu mengevaluasi hasil asuhan keperawatan pada Ny. A dengan gangguan persepsi sensori : halusinasi penglihatan.

6. Mahasiswa mampu melaukukan pendokumentasikan asuhan keperawatan yang diberikan pada Ny. A dengan gangguan persepsi sensori : halusinasi penglihatan 


\section{BAB 2 \\ TINJAUAN TEORI}

\subsection{Konsep Dasar Halusinasi Penglihatan}

\subsubsection{Pengertian}

Halusinasi adalah salah satu gejala gangguan sensori persepsi yang dialami oleh pasien gangguan jiwa, pasien merasakan sensasi berupa suara, penglihatan, pengecapan, perabaan, atau penghiduan tanpa stimulus nyata. (Keliat, 2014). Halusinasi adalah distorsi persepsi palsu yang terjadi pada respons neurobiologis maladaptif. Halusinasi biasanya muncul pada pasien gangguan jiwa diakibatkan terjadinya perubahan orientasi realita, pasien merasakan stimulasi yang sebetulnya tidak ada. halusinasi penglihatan dan pendengaran yang merupakan gejala dari early psychosis, yang sebagian besar terjadi pada usia remaja akhir atau dewasa awal, bingung peran yang berdampak pada rapuhnya kepribadian sehingga terjadi gangguan konsep diri dan menarik diri dari lingkungan sosial yang lambat laun membuat penderita menjadi asik dengan hayalan dan menyebabkan timbulnya halusinasi. (Ervina, 2018).

Dampak yang muncul akibat gangguan halusinasi adalah hilangannya kontrol diri yang menyebabkan seseorang menjadi panik dan perilakunya dikendalikan oleh halusinasi. Dalam situasi ini penderita halusinasi dapat melakukan tindakan merusak lingkungan, mencelakai orang lain, bahkan melakukan bunuh diri Agar tidak berdampak buruk maka penderita halusinasi harus segera ditangani secara tepat. (Scott, 2017) 


\subsubsection{Klasifikasi Halusinasi}

Menurut Yusuf (2015) klasifikasi halusinasi dibagi menjadi 5 yaitu :

\begin{tabular}{|c|c|c|c|}
\hline No & $\begin{array}{l}\text { Jenis } \\
\text { halusinasi }\end{array}$ & Data Objektif & Data Subjektif \\
\hline 1 & $\begin{array}{l}\text { Halusinasi } \\
\text { Pendengaran }\end{array}$ & $\begin{array}{l}\text { 1. Bicara atau tertawa } \\
\text { sendiri tanpa lawan } \\
\text { bicara } \\
\text { 2. Marah-marah tanpa } \\
\text { sebab } \\
\text { mencondongkan } \\
\text { telinga ke arah } \\
\text { tertentu } \\
\text { 3. Menutup telinga }\end{array}$ & $\begin{array}{l}\text { 1. Mendengar suara atau } \\
\text { kegaduhan } \\
\text { 2. Mendengar suara yang } \\
\text { mengajak bercakap-cakap } \\
\text { 3. Mendengar suara yang } \\
\text { menyuruh melakukan } \\
\text { sesuatu yang berbahaya }\end{array}$ \\
\hline 2 & $\begin{array}{l}\text { Halusinasi } \\
\text { penglihatan }\end{array}$ & $\begin{array}{l}\text { 1. Menunjuk-nunjuk } \\
\text { ke arah tertentu } \\
\text { 2. Ketakutan pada } \\
\text { objek yang tidak } \\
\text { jelas }\end{array}$ & $\begin{array}{l}\text { 1. Melihat bayangan, sinar, } \\
\text { bentuk geometris, bentuk } \\
\text { kartun, melihat hantu atau } \\
\text { monster }\end{array}$ \\
\hline 3 & $\begin{array}{l}\text { Halusinasi } \\
\text { penghidu }\end{array}$ & $\begin{array}{l}\text { 1. Menghindu seperti } \\
\text { sedang membaui } \\
\text { bau-bauan tertentu } \\
\text { 2. Menutup hidung }\end{array}$ & $\begin{array}{l}\text { 1. Membaui bau-bauan seperti } \\
\text { bau darah, urine, feses, } \\
\text { 2. kadang-kadang bau itu } \\
\text { menyenangkan }\end{array}$ \\
\hline 4 & $\begin{array}{l}\text { Halusinasi } \\
\text { pengecepan }\end{array}$ & $\begin{array}{l}\text { 1. Sering meludah } \\
\text { 2. Muntah }\end{array}$ & $\begin{array}{l}\text { 1. Merasakan rasa seperti } \\
\text { darah, urine, feses }\end{array}$ \\
\hline 5 & $\begin{array}{l}\text { Halusinasi } \\
\text { perabaan }\end{array}$ & $\begin{array}{l}\text { Menggaruk-garuk } \\
\text { permukaan kulit }\end{array}$ & $\begin{array}{l}\text { 1. Mengatakan ada serangga di } \\
\text { permukaan kulit } \\
\text { 2. Merasa seperti tersengat } \\
\text { listrik }\end{array}$ \\
\hline
\end{tabular}




\subsubsection{Etiologi}

Faktor predisposisi pasien halusinasi menurut ( Oktiviani, 2020 ) :

1. Faktor Predisposisi

a. Faktor perkembangan

Tugas perkembangan pasien terganggu misalnya rendahnya kontrol dan kehangatan keluarga menyebabkan pasien tidak mampu mandiri sejak kecil, mudah frustasi, hilang percaya diri.

b. Faktor sosiokultural

Seseorang yang merasa tidak diterima dilingkungan sejak bayi akan merasa disingkirkan, kesepian, dan tidak percaya pada lingkungan.

c. Biologi

Faktor biologis Mempunyai pengaruh terhadap terjadinya gangguan jiwa. Adanya stress yang berlebihan dialami seseorang maka didalam tubuh akan dihasilkan suatu zat yang dapat bersifat halusinogen neurokimia.Akibat stress berkepanjangan menyebabkan teraktivasinya neurotransmitter otak.

d. Psikologis

Tipe kepribadian lemah dan tidak bertanggung jawab mudah terjerumus pada penyalahgunaan zat adikitif. Hal ini berpengaruh pada ketidakmampuan pasien dalam mengambil keputusan yang tepat demi masa depannya, pasien lebih memilih kesenangan sesaat dan lari dari alam nyata menuju alam khayal.

e. Sosial Budaya

Meliputi pasien mengalami interaksi sosial dalam fase awal dan comforting, pasien meganggap bahwa hidup bersosialisasi di alam nyata sangat membahayakan. Pasien asyik dengan Halusinasinya, seolah-olah ia merupakan tempat untuk 
memenuhi kebutuhan akan interaksi sosial, kontrol diri dan harga diri yang tidak didapatkan dalam dunia nyata.

2. Faktor Presipitasi

Menurut Stuart dan Sudeen faktor presipitasi dapat meliputi (Prabowo, 2014) :

a. Biologis

Gangguan dalam komunikasi dan putaran balik otak, yang mengatur proses informasi serta abnormalitas pada mekanisme pintu masuk dalam otak yang mengakibatkan ketidakmampuan untuk secara selektif menanggapi stimulus yang diterima oleh otak untuk diinterpretasikan.

b. Stress lingkungan

Ambang toleransi terhadap stress yang berinteraksi terhadap stressor lingkungan untuk menentukan terjadinya gangguan perilaku.

c. Sumber koping

Sumber koping mempengaruhi respon individu dalam menanggapi stressor.

\subsubsection{Rentang Respon Neurobiologi}

Rentang respon tersebut dapat digambarkan seperti dibawah ini ( Muhith, 2015 ) :

Adaptif

1. Pikiran logis

2. Persepsi akurat

3. Emosi

konsisten

Dengan

pengalaman

4. Perilaku sesuai

5. Berhubungan

Sosial
Mal adaptif

\begin{tabular}{|l|l|} 
1. Distorsi pikiran & 1. Gangguan pikir/delusi \\
ilusi & 2. Halusinasi \\
2. Reaksi emosi & 3. Sulit merespon emosi \\
berlebihan & 4. Perilaku disorganisasi \\
$\begin{array}{l}\text { 3. Perilaku aneh } \\
\text { atau tidak biasa } \\
\text { 4. Menarik diri }\end{array}$ & 5. Isolasi sosial \\
&
\end{tabular}


Keterangan :

a. Respon adaptif adalah respon yang dapat diterima oleh normanorma sosial budaya yang berlaku. Dengan kata lain individu tersebut dalam batas normal jika menghadapi suatu akan dapat memecahkan masalah tersebut.

Respon adaptif meliputi :

1) Pikiran logis adalah pandangan yang mengarah pada kenyataan

2) Persepsi akurat adalah pandangan yang tepat pada kenyataan

3) Emosi konsisten dengan pengalaman yaitu perasaan yang timbul dari pengalaman ahli.

4) Perilaku sesuai adalah sikap dan tingkah laku yang masih dalam batas kewajaran.

5) Hubungan sosial adalah proses suatu interaksi dengan orang lain dan lingkungan.

b. Respon psikososial meliputi :

1) Proses pikir terganggu yang menimbulkan gangguan

2) Ilusi adalah miss interprestasi atau penilaian yang salah tentang yang benar benar terjadi (objek nyata) karena gangguan panca indra

3) Emosi berlebihan atau kurang

4) Perilaku tidak biasa adalah sikap dan tingkah laku yang melebihi batas untuk menghindari interaksi dengan orang lain

5) Menarik diri adalah percobaan untuk menghindari interkasi dengan orang lain, menghindari hubungan dengan orang lain.

c. Respon maladaptif adalah respon indikasi dalam menyelesaikan masalah yang menyimpang dari norma-norma sosial dan budaya dan lingkungan, adapun respon maladaptif ini meliputi :

1) Kelainan pikiran adalah keyakinan yang secara kokoh dipertahankan walaupun tidak diyakini oleh orang lain dan bertentangan dengan kenyataan sosial 
2) Halusinasi merupakan persepsi sensori yang salah atau persepsi eksternal yang tidak realita atau tidak ada.

3) Kerusakan proses emosi adalah perubahan sesuatu yang timbul dari hati

4) Perilaku tak terorganisir merupakan perilaku yang tidak teratur

5) Isolasi sosial adalah kondisi kesendirian yang dialami oleh individu dan diterima sebagai ketentuan oleh orang lain dan sebagai suatu kecelakaan yang negatif mengancam.

\subsubsection{Fase Halusinasi}

Halusinasi terbagi atas beberapa fase (Oktiviani, 2020 ):

a. Fase Pertama / Sleep disorder

pada fase ini Pasien merasa banyak masalah, ingin menghindar dari lingkungan, takut diketahui orang lain bahwa dirinya banyak masalah. Masalah makin terasa sulit karna berbagai stressor terakumulasi, misalnya kekasih hamil, terlibat narkoba, dikhianati kekasih, masalah dikampus, drop out, dst. Masalah terasa menekan karena terakumulasi sedangkan support sistem kurang dan persepsi terhadap masalah sangat buruk. Sulit tidur berlangsung trus-menerus sehingga terbiasa menghayal. Pasien menganggap lamunanlamunan awal tersebut sebagai pemecah masalah

b. Fase Kedua / Comforting

Pasien mengalami emosi yang berlanjut seperti adanya perasaan cemas, kesepian, perasaan berdosa, ketakutan, dan mencoba memusatkan pemikiran pada timbulnya kecemasan. Ia beranggapan bahwa pengalaman pikiran dan sensorinya dapat dia kontrol bila kecemasannya diatur, dalam tahap ini ada kecenderungan pasien merasa nyaman dengan halusinasinya

c. Fase Ketiga / Condemning 
Pengalaman sensori pasien menjadi sering datang dan mengalami bias. Pasien mulai merasa tidak mampu lagi mengontrolnya dan mulai berupaya menjaga jarak antara dirinya dengan objek yang dipersepsikan pasien mulai menarik diri dari orang lain, dengan intensitas waktu yang lama.

d. Fase Keempat / Controlling Severe Level of Anxiety

Pasien mencoba melawan suara-suara atau sensori abnormal yang datang. Pasien dapat merasakan kesepian bila halusinasinya berakhir. Dari sinilah dimulai fase gangguan psikotik.

e. Fase ke lima / Conquering Panic Level of Anxiety

Pengalaman sensorinya terganggu. Pasien mulai terasa terancam dengan datangnya suara-suara terutama bila pasien tidak dapat menuruti ancaman atau perintah yang ia dengar dari halusinasinya. Halusinasi dapat berlangsung selama minimal empat jam atau seharian bila pasien tidak mendapatkan komunikasi terapeutik. Terjadi gangguan psikotik berat.

\subsubsection{Tanda dan gejala Halusinasi}

Tanda dan gejala gangguan persepsi sensori halusinasi yang dapat teramati sebagai berikut ( Dalami, 2014 ) :

a. Halusinasi penglihatan

1) Melirikkan mata ke kiri dan ke kanan seperti mencari siapa atau apa saja yang sedang dibicarakan.

2) Mendengarkan dengan penuh perhatian pada orang lain yang sedang tidak berbicara atau pada benda seperti mebel.

3) Terlihat percakapan dengan benda mati atau dengan seseorang yang tidak tampak.

4) Menggerakan-gerakan mulut seperti sedang berbicara atau sedang menjawab suara.

b. Halusinasi pendengaran

Adapun perilaku yang dapat teramati 
1) Tiba-tiba tampak tanggap, ketakutan atau ditakutkan oleh orang lain,benda mati atau stimulus yang tidak tampak.

2) Tiba-tiba berlari keruangan lain

c. Halusinasi penciuman

Perilaku yang dapat teramati pada pasien gangguan halusinasi penciuman adalah :

1) Hidung yang dikerutkan seperti mencium bau yang tidak enak.

2) Mencium bau tubuh

3) Mencium bau udara ketika sedang berjalan ke arah orang lain.

4) Merespon terhadap bau dengan panik seperti mencium bau api atau darah.

5) Melempar selimut atau menuang air pada orang lain seakan sedang memadamkan api.

d. Halusinasi pengecapan

Adapun perilaku yang terlihat pada pasien yang mengalami gangguan halusinasi pengecapan adalah :

1) Meludahkan makanan atau minuman.

2) Menolak untuk makan, minum dan minum obat.

3) Tiba-tiba meninggalkan meja makan.

e. Halusinasi perabaan

Perilaku yang tampak pada pasien yang mengalami halusinasi perabaan adalah :

1) Tampak menggaruk-garuk permukaan kulit

Tanda dan gejala halusinasi dinilai dari hasil observasi terhadap pasien serta ungkapan pasien. Adapun tanda dan gejala pasien halusinasi adalah sebagai berikut :

a) Data Subjektif Pasien mengatakan :

1) Mendengar suara-suara atau kegaduhan

2) Mendengar suara yang mengajak bercakap-cakap 
3) Mendengar suara menyuruh melakukan sesuatu yang berbahaya

4) Melihat bayangan, sinar, bentuk geometris, bentuk kartun, melihat hantu dan monster

5) Mencium bau-bauan seperti bau darah, urin, feses, kadang-kadang bau itu menyenangkan

6) Merasakan rasa seperti darah, urin dan feses

7) Merasa takutan atau senang dengan halusinasinya

b) Data Objektif

1) Bicara atau tertawa sendiri

2) Marah marah tanpa sebab

3) Mengarahkan telinga kearah tertentu

4) Menutup telinga

5) Menunjuk kearah tertentu

6) Ketakutan kepada sesuatu yang tidak jelas

7) Mencium sesuatu seperti sedang membaui bau-bauan tertentu

8) Menutup hidung

Sering meludah Menggaruk garuk permukaan kulit

\subsection{Konsep Asuhan Keperawatan}

1) Pengkajian

Pengkajian adalah proses untuk tahap awal dan dasar utama dari proes keperawatan terdiri drai pengumpulan data dan perumusan kebutuhan atau masalah pasien. Data yang dikumpulkan melalui data biologis, psikologis, sosial dan spiritual. Pengelompokkan data pengkajian kesehatan jiwa, dapat berupa faktor presipitasi, penilaian terhadap stressor, sumber koping, dan kemampuan yang dimiliki (Afnuhazi, 2015) : 
a) Identitas pasien

Meliputi nama, umur, jenis kelamain, tanggal pengkajian, tanggal dirawat.

b) Alasan masuk

Alasan pasien datang ke yayasan pemenang jiwa, biasanya pasien sering berbicara sendiri, mendengar atau melihat sesuatu, suka berjalan tanpa tujuan, membanting peralatan dirumah, menarik diri.

c) Faktor predisposisi

1. Biasanya pasien pernah mengalami gangguan jiwa dan kurang berhasil dalam pengobatan

2. Pernah mengalami aniaya fisik, penolakan dan kekerasan dalam keluarga

3. Pasien dengan gangguan orientasi besifat herediter

4. Pernah mengalami trauma masa lalu yang sangat menganggu

d. Faktor Presipitasi

Stresor presipitasi pada pasien dengan halusinasi ditemukan adanya riwayat penyakit infeksi, penyakt kronis atau kelaina stuktur otak, kekerasan dalam keluarga, atau adanya kegagalan kegagalan dalam hidup, kemiskinan, adanya aturan atau tuntutan dalam keluarga atau masyarakat yang sering tidak sesuai dengan pasien serta konflik antar masyarakat.

e. Fisik

Tidak mengalami keluhan fisik.

f. Psikososial

1. Genogram

Pada genogram biasanya terlihat ada anggota keluarga yang mengalami kelainan jiwa, pola komunikasi pasien terganggu begitupun dengan pengambilan keputusan dan pola asuh.

2. Konsep diri 
Gambaran diri pasien biasanya mengeluh dengan keadaan tubuhnya, ada bagian tubuh yang disukai dan tidak disukai, identifikasi diri : pasien biasanya mampu menilai identitasnya, peran diri pasien menyadari peran sebelum sakit, saat dirawat peran pasien terganggu, ideal diri tidak menilai diri, harga diri pasien memilki harga diri yang rendah sehubungan dengan sakitnya.

3. Hubungan sosial : pasien kurang dihargai di lingkungan dan keluarga.

\section{Spiritual}

Nilai dan keyakinan biasanya pasien dengan sakit jiwa dipandang tidak sesuai dengan agama dan budaya, kegiatan ibadah pasien biasanya menjalankan ibadah di rumah sebelumnya, saat sakit ibadah terganggu atau sangat berlebihan.

\subsubsection{Diagnosa Keperawatan}

Dengan faktor berhubungan dan batasan karakteristik disesuaikan dengan keadaan yang ditemukan pada tiap-tiap partisipan. Topik yang diteliti yakni kemampuan mengontrol halusinasi dengar (Aji, 2019).

\subsubsection{Perencanaan Keperawatan}

Rencana tindakan pada keluarga (Keliat, 2014) adalah ;

1. Diskusikan masalah yang dihadap keluarga dalam merawat pasien

2. Berikan penjelasan meliputi : pengertian halusinasi, proses terjadinya halusinasi, jenis halusinasi yang dialami, tanda dan gejala halusinasi, proses terjadinya halusinasi.

3. Jelaskan dan latih cara merawat anggota keluarga yang mengalami halusinasi : menghardik, minum obat, bercakap-cakap, melakukan aktivitas.

4. Diskusikan cara menciptakan lingkungan yang dapat mencegah terjadinya halusinasi.

5. Diskusikan tanda dan gejala kekambuhan 
6. Diskusikan pemanfaatan fasilitas pelayanan kesehatan terdekat untuk follow up anggota keluarga dengan halusinasi.

\subsubsection{Implementasi}

1. Bina hubungan saling percaya (BHSP)

2. Identifikasi, waktu, frekuensi, situasi, respon pasien terhadap halusinasi

3. Melatih pasien mengontrol halusinasi dengan cara menghardik

4. Melatih pasien mengontrol halusinasi dengan cara patuh minum obat

5. Melatih pasien dengan cara bercakap-cakap

6. Melatih pasien mengontrol halusinasi dengan cara melaksanakan kegiatan terjadwal (Siti, 2021)

\subsubsection{Evaluasi Keperawatan}

Evaluasi adalah proses hasil atau sumatif dilakukan dengan membandingkan respon pasien pada tujuan umum dan tujuan khusus yang telah ditentukan.halusinasi pendengaran tidak terjadi perilaku kekerasan, pasien dapat membina hubungan saling percaya, pasien dapat mengenal halusinasinya, pasien dapat mengontrol halusinasi dengar dari jangka waktu 4x24 jam didapatkan data subjektif keluarga menyatakan senang karena sudah diajarkan teknik mengontrol halusinasi, keluarga menyatakan pasien mampu melakukan beberapa teknik mengontrol halusinasi. Data objektif pasien tampak berbicara sendiri saat halusinasi itu datang, pasien dapat berbincang-bincang dengan orang lain, pasien mampu melakukan aktivitas terjadwal, dan minum obat secara teratur ( Aji, 2019) 


\section{BAB 3 \\ TINJAUAN KASUS}

\subsection{Identitas Pasien}

Inisial

Ruang Rawat

Tanggal Pengkajian

Umur

Agama

Informan

jiwa
: Ny. A

: Yayasan pemenang jiwa sumatera utara

: 3 maret 2021

: 39 Tahun

: Buddha

: Pasien dan pegawai Yayasan Pemenang

\subsection{Alasan Masuk}

Pasien Awalnya marah-marah karena kesal, melamun, sering bicara sendiri, mondar mandir, mendengar suara-suara tanpa wujud, sering melihat orangorang arab tanpa wujud, tertawa sendiri.

\subsection{Faktor Predisposisi}

Pasien sebelumnya mengalami gangguan jiwa sejak SMP kelas 1 dan sebelumnya juga pasien belum pernah dibawa ke yayasan pemenang jiwa. Dirumah pasien tidak pernah minum obat, sehingga timbul gejala-gejala seperti diatas. Pasien awalnya marah-marah dan melempar barang-barang karena kesal, suka menyendiri, melamun, sering bicara sendiri, mondar mandir, mendengar suara-suara tanpa wujud, tertawa sendiri akhirnya keluarga membawa pasien ke Yayasan Pemenang Jiwa Provinsi Sumatera Utara pada tanggal 16 Januari 2016 . Keluarga pasien tidak ada yang pernah mengalami gangguan jiwa.

\subsection{Fisik}

Pasien tidak memiliki keluhan fisik, saat dilakukan pemeriksaan tanda-tanda vital, didapatkan hasil TD : 110/80 mmHg ; N : 82x/i ; S : 36, $5^{\circ} \mathrm{C} ; \mathrm{P}: 20 \mathrm{x} / \mathrm{i}$. Pasien memiliki tinggi badan $168 \mathrm{~cm}$ dan berat badan $67 \mathrm{Kg}$. 


\subsection{Psikososial}

\subsubsection{Genogram}

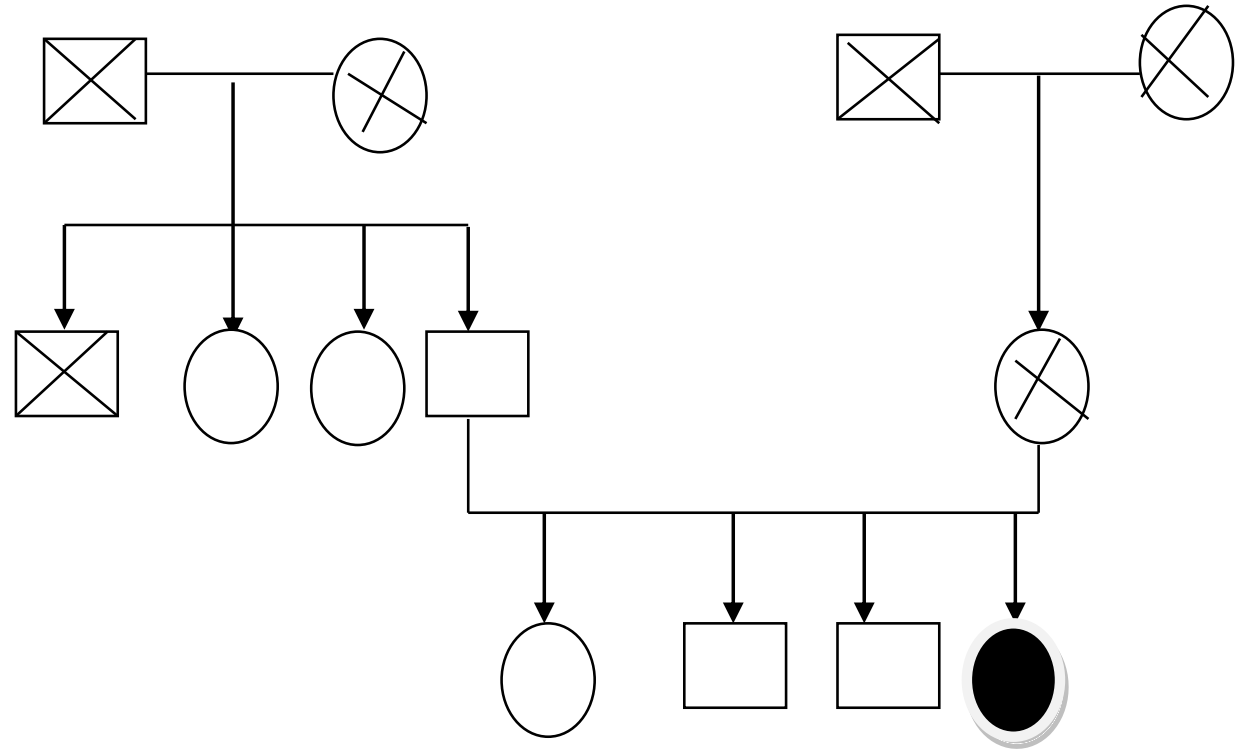

Penjelasan :

Pasien merupakan anak keempat dari 4 bersaudara, pasien memiliki 2 abang dan 1 kakak perempuan. Pasien belum menikah.

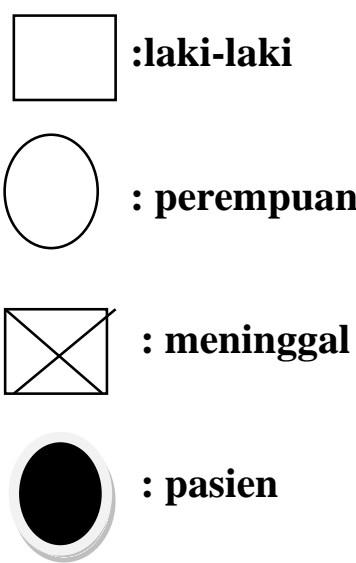

\subsubsection{Konsep diri}

a) Gambaran diri : pasien menyukai tubuhnya yang tidak ada cacat.

b) Identitas : pasien anak ke 4 dari 4 bersaudara

c) Peran : pasien hanya sempat sekolah SMP kelas 1 yang saat ini tidak memiliki pekerjaan 
d) Ideal diri : pasien sudah merasa bosan dan ingin secepatnya pulang ke rumah.

e) Harga diri : pasien merasa malu berada di YPJ dan merasa bosan

\subsubsection{Hubungan social}

Pasien mengganggap bahwa keluarganya adalah orang yang sangat berarti dalam hidupnya, terutama orangtuanya. Pasien mengatakan tidak mengikuti kegiatan di kelompok/masyarakat. Pasien mengatakan mempunyai hambatan dalam berhubungan dengan orang lain karena pasien sulit bergaul dan selalu ingin menyendiri dan pasien juga beranggapan bahwa orang-orang yang disekitanya jahat dan suka mara-marah

\subsubsection{Spiritual}

Nilai dan Keyakinan : Pasien beragama kristen dan yakin dengan agamanya.

a. Kegiatan Ibadah : Pasien melakukan ibadah selama dirawat.

\subsubsection{Status Mental}

1. Penampilan pasien rapi seperti berpakaian biasa pada umum nya.

2. Pembicaraan Pasien bicara dengan lambat.

3. Aktivitas Motorik

Pasien mengatakan bisa melakukan aktivitas sehari - hari.

4. Suasana perasaan

kliien tidak mampu mengepresikan perasaan nya pada saat mendengarkan suara - suara.

Masalah keperawatan ; Gangguan Sensori Persepsi : Halusinas

5. Afek :

wajah sesuai dengan topik pembicaraan

6. Interaksi selama wawancara

Pasien kooperatif saat wawancara 
7. Persepsi

Pasien mengatakan bahwa ia mendengar ada suara-suara

Masalah keperawatan : Gangguan persepsi sensori : halusinasi

8. Proses Pikir

Pasien mampu menjawab apa yang ditanya dengan

9. Isi pikir

Pasien dapat mengontrol isi pikirnya,pasien tidak mengalami gangguan isi pikir dan tidak ada waham. Pasien tidak mengalami fobia, obsesi ataupun depersonalisasi.

10. Tingkat kesadaran

Pasien tidak mengalami gangguan orientasi, pasien mengenali waktu, orang dan tempat.

11. Memori

Pasien mampu menceritakan kejadian di masa lalu dan yang baru terjadi.

12. Tingkat konsentrasi berhitung

Pasien mampu berkonsentrasi dalam perhitungan sederhana tanpa bantuan orang lain.

13. Kemampuan penilaian

Pasien dapat membedakan hal yang baik dan yang Daya tilik diri Pasien tidak mengingkari penyakit yang diderita, pasien mengetahui bahwa dia sedang sakit dan dirawat di rumah sakit jiwa buruk (mampu melakukan penilaian).

\subsection{Mekanisme Koping}

Pasien mengalami mekanisme koping adaptif yaitu pasien dapat berbicara baik dengan orang lain. 


\subsection{Masalah Psikososial dan Lingkungan}

Pasien mengatakan sulit berteman dengan orang lain karena pasien selalu ingin menyendiri.

\subsection{Pengetahuan Kurang Tentang Gangguan Jiwa}

Pasien tidak mengetahui tentang gangguan jiwa yang di alaminya dan obat yang dikonsumsinya.

\subsection{Aspek Medik}

Diagnosa medis : Skizofrenia Paranoid

Terapi medis yang diberikan:

Resperidon tablet $2 \mathrm{mg} 2 \mathrm{x} 1$

\subsection{Analisa Data}

\begin{tabular}{|l|c|c|}
\hline No & Data & Masalah keperawatan \\
\hline 1 & Ds : & Gangguan persepsi sensori \\
& - Staf pegawai mengatakan, bahwa & : halusinasi penglihatan \\
& pasien suka tertawa sendiri dan & \\
berteriak & \\
& - Pasien sering melihat orang-orang & \\
& asing seperti : orang arab, tanpa & \\
& wujud dan terkadang mendengar & \\
suara-suara bisikan. & \\
& Pasien mengatakan orang arab & \\
yang tanpa wujud tersebut & \\
muncul 3 kali/ hari disaat dia & \\
& menyendiri dan ketika melihat & \\
& - Pasien sangat takut dan gelisah & \\
& &
\end{tabular}




\begin{tabular}{|c|c|c|}
\hline & $\begin{array}{l}\text { jika melihat orang arab tersebut. } \\
\text { DO : } \\
\text { - Pasien sering bicara ngawur, } \\
\text { terkadang bicara sendiri, } \\
\text { senyum-senyum sendiri. }\end{array}$ & \\
\hline 2 & $\begin{array}{l}\text { Ds : } \\
\text { Pasien mengatakan tidak mengikuti } \\
\text { kegiatan di kelompok/masyarakat. } \\
\text { Pasien mengatakan mempunyai } \\
\text { hambatan dalam berhubungan } \\
\text { dengan orang lain karena pasien sulit } \\
\text { bergaul dan selalu ingin menyendiri. } \\
\text { Do : } \\
\text { Pasien tampak menghindari } \\
\text { interaksi, terlihat sedih, pendangan } \\
\text { menunduk kebawah }\end{array}$ & $\begin{array}{l}\text { Isolasi Sosial : Menarik } \\
\text { Diri }\end{array}$ \\
\hline 3 & $\begin{array}{l}\text { Ds: } \\
\text { Pasien mengatakan malu dan malas } \\
\text { berinteraksi dengan orang lain, pasien } \\
\text { merasa dibuang oleh keluarganya, malu } \\
\text { karena tidak mempunyai pekerjaan dan } \\
\text { penghasilan sendiri, pasien memilih } \\
\text { memendam masalahnya sendiri, } \\
\text { Do : } \\
\text { Pasien tampak lemah dan tidak } \\
\text { bersemangat, kontak mata kurang, } \\
\text { pasien lebih sering menyendiri. }\end{array}$ & Harga Diri Rendah \\
\hline
\end{tabular}




\subsection{Pohon Masalah}

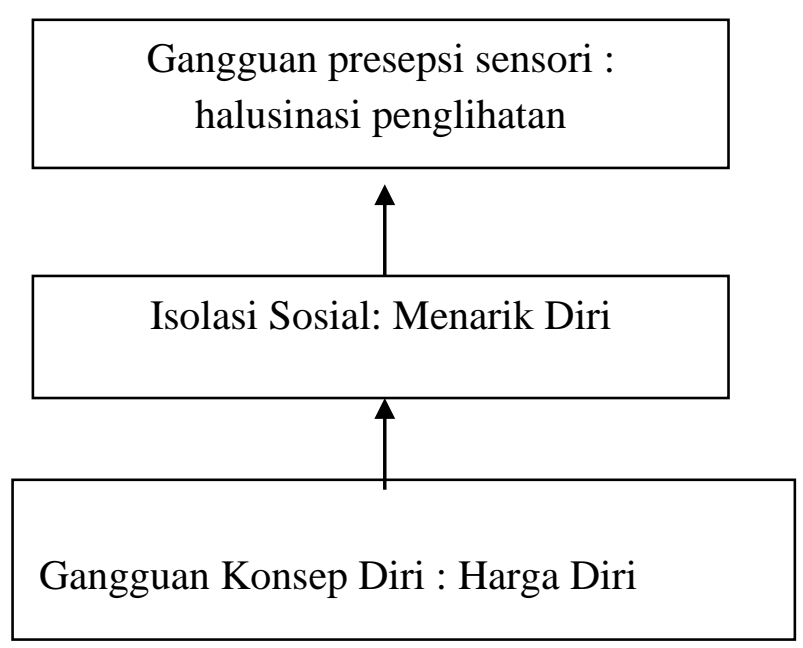

\subsection{Prioritas Diagnosa Keperawatan}

1. Gangguan Persepsi Sensori : Halusinasi

2. Isolasi sosial : menarik diri

\subsection{Intervensi Keperawatan}

\begin{tabular}{|c|c|c|}
\hline No & Diagnosa & Intervensi \\
\hline 1 & $\begin{array}{l}\text { Gangguan persepsi sensori : } \\
\text { halusinasi } \\
\text { DO : } \\
\text { Pasien sering bicara ngawur, } \\
\text { terkadang bicara sendiri, senyum- } \\
\text { senyum sendiri. }\end{array}$ & $\begin{array}{l}\text { SP 1: } \\
\text { 1. Identifikasi isi, waktu terjadi, } \\
\text { situasi pencetus, dan respon } \\
\text { terhadap halusinasi } \\
\text { 2. Mengontrol halusinasi dengan } \\
\text { cara menghardik } \\
\text { SP 2: } \\
\text { Mengontrol Halusinasi dengan cara } \\
\text { minum obat secara teratur }\end{array}$ \\
\hline
\end{tabular}




\begin{tabular}{|c|c|c|}
\hline & $\begin{array}{l}\text { mengatakan bahwa pasien } \\
\text { suka tertawa sendiri dan } \\
\text { berteriak } \\
\text { - Pasien sering melihat orang- } \\
\text { orang asing seperti : orang } \\
\text { arab, tanpa wujud dan } \\
\text { terkadang mendengar } \\
\text { suara-suara bisikan. } \\
\text { - Pasien mengatakan orang } \\
\text { arab yang tanpa wujud } \\
\text { tersebut muncul } 3 \text { kali/ } \\
\text { hari disaat dia menyendiri } \\
\text { dan ketika melihat orang } \\
\text { ramai. } \\
\text { - Pasien sangat takut dan } \\
\text { gelisah jika melihat orang } \\
\text { arab tersebut. }\end{array}$ & $\begin{array}{l}\text { SP 3: } \\
\text { mengontrol halusinasi dengan cara } \\
\text { bercakap - cakap dengan orang lain } \\
\text { SP 4: } \\
\text { mengontrol halusinasi dengan cara } \\
\text { melakukan aktifitas terjadwal }\end{array}$ \\
\hline 2 & Isolasi sosial & $\begin{array}{l}\text { Bina hubungan saling percaya dengan } \\
\text { Mengemukakan prinsip komunikasi } \\
\text { terapeutik } \\
\text { Sp1: } \\
\text { Menjelaskan keuntungan dan kerugian } \\
\text { mempunyai teman } \\
\text { Sp2: } \\
\text { Melatih pasien dengan berkenalan } \\
\text { dengan } 2 \text { orang } \\
\text { Sp3: } \\
\text { Melatih pasien bercakap-cakap sambil } \\
\text { melakukan kegiatan harian. } \\
\text { Sp4 : } \\
\text { Melati berbicara sosial: seperti }\end{array}$ \\
\hline
\end{tabular}




\begin{tabular}{|l|l|}
\hline & $\begin{array}{l}\text { meminta sesuatu, berbelanja dan } \\
\text { sebagainya. }\end{array}$ \\
\hline
\end{tabular}

\subsubsection{Implementasi dan Evaluasi}

\begin{tabular}{|c|c|c|}
\hline Waktu & Implementasi & Evaluasi \\
\hline $\begin{array}{l}09 \text { maret } \\
2021\end{array}$ & $\begin{array}{l}\text { 1. Data } \\
\text { Tanda dan gejala :bicara } \\
\text { sendiri, marah }- \text { marah } \\
\text { tanpa sebab } \\
\text { memalingkan muka ke } \\
\text { arah telinga, ketakutan } \\
\text { pada suatu yang tidak } \\
\text { jelas. } \\
\text { 2.Diagnosa Keperawatan } \\
\text { Husinasi penglihatan. } \\
\text { 3.Tindakan Keperawatan } \\
\text { Sp1 halusinasi } \\
\text { 1.Identifikasi isi, waktu } \\
\text { terjadi, sitausi pencetus, dan } \\
\text { respon terhadap halusinasi. } \\
\text { 2.Mengontrol halusinasi } \\
\text { dengan cara menghardik } \\
\text { 4.RTL mengontrol halusinasi } \\
\text { dengan cara minum obat }\end{array}$ & $\begin{array}{l}\text { S : Senang } \\
\text { O : } \\
\text { - } \text { Pasien mampu mengenali } \\
\text { halusinasi yang dialami nya: isi, } \\
\text { frekuensi, waktu terjadi, sruasi } \\
\text { pencetus,perasaan, respon dengan } \\
\text { mandiri } \\
\text { P : Halusinasi (+) } \\
\text { - } \\
\text { Pasien mampu } \\
\text { halusinasinya dengan cara } \\
\text { menghardik dengan mandiri } \\
\text { Latihan halusinasinya; isi, frekuensi, } \\
\text { watu terjadi, sruasi pencetus, } \\
\text { perasaan dan respon halusinasi } \\
\text { 3x/hari } \\
\text { Latihan menghardik halusinasi } \\
\text { 3x/ hari }\end{array}$ \\
\hline
\end{tabular}




\begin{tabular}{|c|c|c|}
\hline & $\begin{array}{l}\text { Sp3; mengontrol halusinasi } \\
\text { dengan cara bercakap - } \\
\text { cakap }\end{array}$ & \\
\hline $\begin{array}{l}12 \text { maret } \\
2021 \\
\text { Jam } 10: 30\end{array}$ & $\begin{array}{l}\text { 1. Data } \\
\text { Tanda dan gejala : bicara } \\
\text { atau tertawa sendiri, } \\
\text { mudah marah - ketakutan } \\
\text { pada suatu yang tidak } \\
\text { jelas, sering meludah.. } \\
\text { Kemampuan: } \\
\text { 2. Diagnosa keperawatan } \\
\text { Halusinasi } \\
\text { 3. Tindakan keperawatan } \\
\text { Sp4 : Halusinasi } \\
\text { - Mengevaluasi } \\
\text { kemampuan } \\
\text { Menghardik } \\
\text { Halusinasi } \\
\text { evaluasi Sp 1-4 Halusinasi } \\
\text { - Melatih pasien untuk } \\
\text { melakukan kegiatan } \\
\text { spritual dengan cara } \\
\text { berdoa. }\end{array}$ & $\begin{array}{l}\text { S : pasien mengatakan dia merasa } \\
\text { senang bisa bercakap-cakap dengan } \\
\text { orang lain } \\
\mathrm{O} \text { : Pasien mempraktekkan cara } \\
\text { bercakap-cakap dengan orang lain } \\
\text { A : Halusinasi penglihatan (+) } \\
\text { P : Intervensi dilanjutkan } \\
\text { - Latihan menghardik halusinasi } \\
\quad 3 \text { x/ hari } \\
\text { - Latihan minum obat dengan } \\
\text { prinsip } 6 \text { benar } 2 \text { x/ hari } \\
\text { - Latihan bercakap-cakap } \\
\text { dengan orang lain } 3 x / \text { hari } \\
\text { Latihan kegiatan spritual }\end{array}$ \\
\hline $\begin{array}{l}19 \text { maret } \\
2021\end{array}$ & $\begin{array}{l}\text { Diagnosa keperawatan : } \\
\text { Isolasi sosial. }\end{array}$ & $\begin{array}{l}\text { S: Senang, wajah cerah } \\
\text { O: - Pasien dapat menyebutkan }\end{array}$ \\
\hline
\end{tabular}




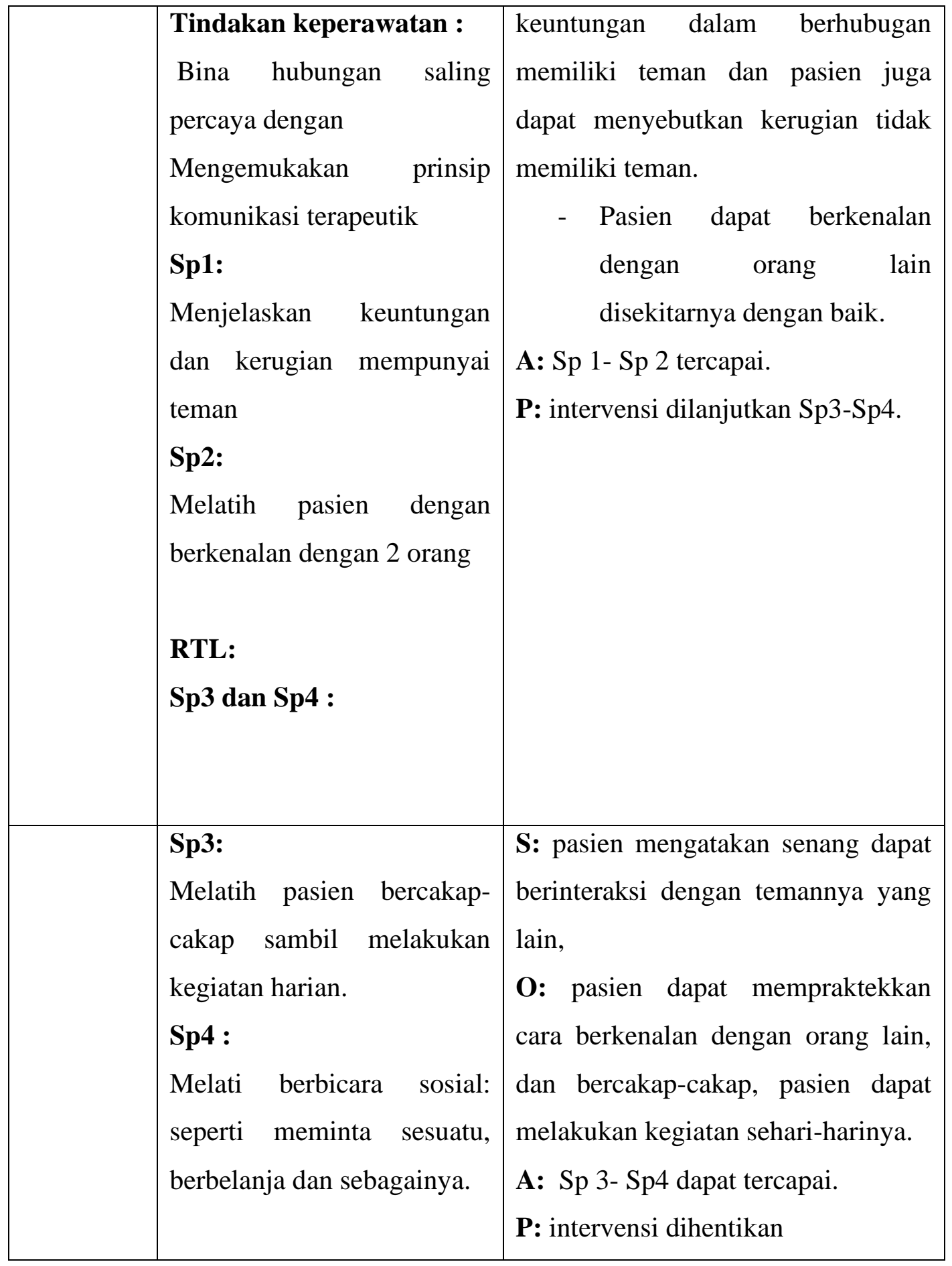




\section{BAB 4 \\ PEMBAHASAN}

Setelah penulis melaksanakan asuhan keperawatan kepada Ny. A dengan gangguan sensori persepsi: halusinasi penglihatan di Yayasan pemenang jiwa sumatra utara, maka penulis pada $\mathrm{BAB}$ ini akan membahas kesenjangan antara teoritis dengan tinjauan kasus. Pembahasan dimulai melalui tahapan proses keperawatan yaitu pengkajian, diagnosa keparawatan, perencanaan, pelaksanaan dan evaluasi.

\subsection{Pengkajian}

Pada pembahasan ini diuraikan tentang hasil pelaksanaan tindakan keperawatan dengan pemberian terapi generalis pada pasien halusinasi penglihatan. Pembahasan menyangkut analisis hasil penerapan terapi generalis terhadap masalah keperawatan halusinasi penglihatan. Tindakan keperawatan didasarkan pada pengkajian dan diagnosis keperawatan yang terdiri dari tindakan generalis yang dijabarkan sebagai berikut.

Tahap pengkajian pada pasien halusinasi dilakukan interaksi perawat-pasien melalui komunikasi terapeutik untuk mengumpulkan data dan informasi tentang status kesehatan pasien. Pada tahap ini terjadi proses interaksi manusia, komunikasi, transaksi dengan peran yang ada pada perawat sebagaimana konsep tentang manusia yang bisa dipengaruhi dengan adanya proses interpersonal.

Selama pengkajian dilakukan pengumpulan data dari beberapa sumber, yaitu dari pasien dan tenaga kesehatan di ruangan. Penulis mendapat sedikit kesulitan dalam menyimpulkan data karena keluarga pasien jarang mengunjungi pasien di rumah sakit jiwa. Maka penulis melakukan pendekatan kepada pasien melalui komunikasi terapeutik yang lebih terbuka membantu pasien untuk memecahkan perasaannya dan juga melakukan observasi kepada pasien. 
Adapun upaya tersebut yaitu:

a. Melakukan pendekatan dan membina hubungan saling percaya diri pada pasien agar pasien lebih terbuka dan lebih percaya dengan menggunakan perasaan.

b. Mengadakan pengkajian pasien dengan wawancara

c. Mengadakan pengkajian dengan cara membaca status, melihat buku rawatan dan bertanya kepada pegawai ruangan sorik merapi.

Dalam pengkajian ini, penulis menemukan kesenjangan karena ditemukan. Pada kasus Ny. A, pasien melihat dan mendengar suara-suara yang menyuruh untuk berteriak-teriak ,gelisah, mondar-mandir, tampak tegang, putus asa, sedih dan lain-lain. Gejala gejala yang muncul tersebut tidak semua mencakup dengan yang ada di teori klinis dari halusnasi (Keliat,.2014). Akan tetapi terdapat faktor predisposisi maupun presipitasi yang menyebabkan kekambuhan penyakit yang dialami oleh $\mathrm{Ny}$. A.

Tindakan keperawatan terapi generalis yang dilakukan pada Ny. A adalah strategi pertemuan pertama sampai pertemuan empat. Strategi pertemuan pertama meliputi mengidentifikasi isi, frekuensi, jenis, dan respon pasien terhadap halusinasi serta melatih cara menghardik halusinasi. Strategi pertemuan kedua yang dilakukan pada Ny. A meliputi melatih cara mengendalikan dengan bercakap-cakap kepada orang lain. Strategi pertemuan yang ketiga adalah menyusun jadwal kegiatan bersama-sama dengan pasien. Strategi pertemuan keempat adalah mengajarkan dan melatih Ny. A cara minum obat yang teratur

\subsection{Diagnosa Keperawatan}

Menurut marlina (2020) diagnosa keperawatan yang muncul sebanyak 3 diagnosa keperawatan (Aji, 2019) yang meliputi:

1. Harga diri rendah

2. Isolasi social 


\section{Halusinasi}

Sedangkan pada kasus Ny. A ditemukan lima diagnosa keperawatan yang muncul yang meliputi: harga diri rendah, isolasi sosial, halusinasi, koping individu inefektif, regimen teraupetik inefektif. Dari hal tersebut di atas dapat dilihat terjadi kesamaan antara teori dan kasus. Dimana semua diagnosa pada teori muncul pada kasus Ny. A.

\subsection{Implementasi}

Implementasi, adalah tahap dimana perawat memulai melakukan tindakan penulis hanya mengatasi masalah keperawatan halusinasi penglihatan. Dengan melakukan strategi pertemuan yaitu mengidentifikasi isi, frekuensi, waktu terjadi, perasaan, respon halusinasi. Kemudian strategi pertemuan yang dilakukan yaitu latihan mengontrol halusinasi dengan cara menghardik. Strategi pertemuan yang kedua yaitu anjurkan minum obat secara teratur, strategi pertemuan yang ke tiga yaitu latihan dengan cara bercakap - cakap pada saat aktivitas dan latihan strategi pertemuan ke empat yaitu melatih pasien melakukan kegiatan terjadwal.

\subsection{Evaluasi}

Pada tinajauan teoritis evaluasi yang diharapkan adalah: Pasien mempercayai perawat sebagai terapis, pasien menyadari bahwa yang dialaminya tidak ada objeknya, dapat mengidentifikaasi halusinasi, dapat mengendalikan halusinasi melalui mengahrdik, latihan bercakap-cakap, melakukan aktivitas serta menggunakan obat secara teratur Pada tinjauan kasus evaluasi yang didapatkan adalah: Pasien mampu mengontrol dan mengidentifikasi halusinasi, Pasien mampu melakukan latihan bercakap-cakap dengan orang lain, Pasien mampu melaksanakan jadwal yang telah dibuat bersama, Pasien mampu memahami penggunaan obat yang benar: 5 benar. Selain itu, dapat dilihat dari setiap evalusi yang dilakukan pada asuhan keperawatan, dimana terjadi penurunan gejala yang dialami oleh Ny. A dari hari kehari selama proses interaksi. 


\section{DAFTAR PUSTAKA}

Afnuhazi \& Ridhyalla. (2015). Komunikasi Terapeutik Dalam Keperawatan Jiwa.

Aji, W. M. H. (2019). Asuhan Keperawatan Orang Dengan Gangguan Jiwa Halusinasi Dengar Dalam Mengontrol Halusinasi. https://doi.org/10.31219/osf.io/n9dgs

Dalami E, dkk. (2014). Asuhan Keperawatan Pasien Dengan Gangguan Jiwa. Jakarta: CV. Trans Info Media.

Ervina,I., \& Hargiana, G. (2018). Aplikasi keperawatan Generalis dan Psikoreligius pada pasien pada gangguan sensori persepsi: Halusinasi penglihatan dan pendengaran. Jurnal Riset Kesehatan Nasional, 2(2), 114-123. http://dx.doi.org/10.37294/jrkn.v2i2.106

Keliat B, dkk. (2014). Proses Keperawatan Jiwa Edisi II. Jakarta : EGC.

Kusmiawati, Farida dan Yudi Hartono. (2012). Buku Ajar Keperawatan Jiwa Jakarta : Salemba Medika

M. (2021, March 18). Asuhan Keperawatan Jiwa Pada Ny. L Dengan Masalah Halusinasi Pendengaran. https://doi.org/10.31219/osf.io/tghms

Muhith, Abdul. (2015). Pendidikan Keperawatan Jiwa. Jakarta: Penerbit ANDI.

Oktiviani, D. P. (2020). Asuhan Keperawatan Jiwa Pada Tn. K dengan masalah Gangguan Persepsi Sensori: Halusinasi Pendengaran di Ruang Rokan Rumah Sakit Jiwa Tampan. Skripsi, Poltekkes Kemenkes Riau. http://repository.pkr.ac.id/id/eprint/498

Pardede, J. (2020). Family Knowledge about Hallucination Related to Drinking Medication Adherence on Schizophrenia Patient. Jurnal Penelitian Perawat Profesional, 2(4), 399-408. https://doi.org/10.37287/jppp.v2i4.183

Pardede, J. A., \& Hasibuan, E. K. (2020). Lamanya Perawatan Pasien Skizofrenia Rawat Jalan Dengan Tingkat Stres Keluarga. Indonesian Trust Health Journal, 3(1), 283-288. https://doi.org/10.37104/ithj.v3i1.49

Pardede, J. A., Silitonga, E., \& Laia, G. E. H. (2020). The Effects of Cognitive Therapy on Changes in Symptoms of Hallucinations in Schizophrenic Patients. Indian Journal of Public Health Research \& Development, 11(10).

Pardede, J.A.,\& Siregar, R.A. (2016). Pendidikan Kesehatan Keptauhan Minum Obat Terhadap Perubahan Gejala Halusinasi Pada pasien skizofrenia. Mental Health, 3(1) 
Prabowo, E. (2014). Konsep \& Aplikasi Asuhan Keperawatan Jiwa. Yogyakarta: Nuha Medika.

Riskesdas (2018). Kementrian Kesehatan RI, badan peneliatian dan pengembangan kesehatan. https://kesmas.kemkes.go.id/assets/upload/di

Scott, J., \& Connell, M. (2017). Halluconations in adolescents an risk of mental disorders and psychosocial impairment in adulthood: a birth cohor study. Schizophrenia Bulletin, 43(1), 58. https://www.ncbi.nlm.nih.gov/pmc/articles/PMC5475452/

Mahmudah, S,,(2021). Asuhan Keperawatan Jiwa Pada Pasien Dengan Gangguan Halusinasi (Doctoral Dissertation, Universitas Kusuma Husada Surakarta).

http://eprints.ukh.ac.id/id/eprint/1497/1/Naskah\%20Publikasi\%20Siti \%20Mahmudah.pdf

Stuart, G. W. (2013). Buku Saku Keperawatan Jiwa . Edisi 5. Jakarta. EGC.

Stuart, Gail, W. (2016). Prinsip dan Praktik Keperwatan Kesehatan Jiwa. (B. A. Kelliat, Ed.) (1st ed.). Singapore.

Townsend, M. C. (2014). Psychiatric Mental Healt Nursing : Concepts of Care in Evidence-Based Practice (6thed.), Philadelphia: F.A. Davis.

WHO (2019). Schizophrenia. Retrieved from. https://www.who.int/newsroom/fact sheets/\%20detail/schizophrenia

Yusuf, Ahmad Dkk. (2015). Buku Ajar Keperawatan Kesehatan Jiwa. Jakarta: Salemba Medika 